\title{
ГЛАГОЛСКИ И ЗАМЕНИЧКИ ОБЛИЦИ ЗА 1. Л. МН. С НЕНАВЕДЕНИМ РЕФЕРЕНТОМ И ЗАВИСНОСТ ЮИХОВЕ РЕФЕРЕНЦИЈЕ ОД КОНТЕКСТА
}

\begin{abstract}
Циљ овог рада је да се осврне на утицај контекста при одређивању референције личних облика, заменичких или глаголских, за 1. л.мн. Ради остварења тог циља се издвајају посебне врсте употребе поменутих облика, врши се њихова семантичка анализа и извлаче се закључци о различитим механизмима постизања идентификације референтног скупа. Спроводи се битна разлика међу конкретнореферентним и генерализованим значењем разматраних личних облика.

Кључне речи: референција, контекст, генерализовано значење.
\end{abstract}

У литератури је већ одавно постављен проблем посебности значења код заменица, које, за разлику од осталих аутосемантичких речи, не називају појмове. Њихово значење аутори обично своде на један од следећа два аспекта - заменице замењују имена, тј. имају природу супститута, или заменице указују како на целу класу речи (различите врсте речи), тако и на посебне индивидуе.

1. Овде ће нас занимати значење личних заменица 1. лица. Емил Бенвенист сматра да се личне заменице 1. и 2. лица ја и ти саодносе са сваким посебним говорним чином, са сваком посебном употребом у којој ја означује говорника, а $m и$ - оног коме се говорник обраћа. Он назива те заменице „,празни” значи слободни од референтног саодноса са „стварношћу”, увек спремни за нову употребу (Бенвенист 1974). Међутим, аутор не разматра посебно те заменице у облику за множину. Бугарска лингвисткиња Р. Ницолова приказује значење заменица првог и другог лица у виду хијерархије прива-

\footnotetext{
*dimkasav@abv.bg
} 
тивних опозиција. Као референте заменица првог и другог лица у множини она одређује скуп референата у који улази бар један учесник говорног чина. Посебно за заменицу ми аутор прецизира да она најчешће означава нехомогени скуп којем осим говорника може да припада (али необавезно) и слушалац. У првом случају укључивање у референтни скуп још и неког трећег лица (лица̂) јесте факултативно, а у другом случају јесте обавезно (Ницолова 1986). У граматици хрватског језика забележено је да се заменица ми ... ироtrebljava onda kad govornik govori u svoje ime i u ime onih koji misle kao on ili po bilo čemu pripadaju istoj grupi kao on, ..., ili onda kad hoće obuhvatiti sebe $i$ sugovornika... (Барић и др. 2005).

Због истакнуте везе заменице 1 . лица са говорном ситуацијом и са деиксом, природна је њена употреба у дијалогу, где указивање на учеснике говорног чина игра основну улогу - најмање зато што се стално врши промена комуникативних функција (говорник - саговорник). Тада је због опасности од комуникативног неуспеха природно да група која укључује говорника +/- саговорника буде максимално јасна.

Међутим, у монолошком тексту се идентификација говорника (аутора) и његове групе референата не врши преко указивања у говорној ситуацији и зато је она, уколико референтни скуп није изричито поменут (што је пре изузетак него правило), везана за веће когнитивне напоре. Тада се у први план истиче шири или ужи контекст као основни чинилац за идентификацију референата, што код дијалога одговара говорној ситуацији (мада и у дијалогу контекст може да врши улогу код идентификације референтног скупа). У овом раду ћемо покушати да представимо неке специфичније механизме за идентификацију референтног скупа у зависности од контекста.

2. Осврнућемо се најпре на случајеве у којима језички израз реферише о скупу конкретних референата, који нису сасвим уочљиви, али се подразумевају из појединих елемената контекста.

2.1. У неким случајевима је конкретни скуп референата јаснији и читалац га препознаје уз мање напора помоћу елементарних логичких операција. Нпр. у одломку текста Mima se, inače pojavljivala iznenada ispod krila-F, uvek nekako promenjena, kao nova. ... Ponekad je ne bismo videli i po mesec dana, a odmah posle tako dugog odsustva pojavljivala bi se pet večeri uzastopce... (MK) референтни субјекти се ишчитавају из комбинације између оних који станују у студентском граду, у $\boldsymbol{k r i l u - F , ~ и ~ о н и х ~ к о ј и ~ з н а ј у ~ и ~ о ч е к у ј у ~ д а ~ в и д е ~ д о т и ч н у ~}$ Миму - тако референција обухвата двојицу младића, главних јунака књиге.

У другим случајевима уместо упућујућег елемента из контекста говорник (аутор) користи катафору, која конкретизује референцију израза претпостављену из претходног контекста: Topli vetrovi koji su nedeljama duvali bez prestanka bili su puni prijatnih nagoveštaja. Naši zimski kaputi otežaše preko noći, a kolena nam postaše klecava. Neki slatki đavo uselio se za sto u Kolarcu. Pitaćete se, sigurno, zbog čega je za mene i moje prijatelje bila toliko važna jedna kafana kao što je Kolarac? (MK).

Како у дијалогу тако и у монолошком тексту конкретни скуп референата може да се формира и на основу супротстављања, као скуп који асоцира 
(али са супротним знаком) с другим референтом или референтима који су названи, нпр.: Govore da je spoznaja božje mudrosti moguća samo odabranima, samo rijetkima. - A šta ostaje nama? - Da spoznamo ono što možemo (MC). Компликованију варијанту исте појаве имамо у следећем монолошком тексту, где референт, од којег се са супротним знаком добија конкретни скуп, није директно поменут: Tako i ne prestaje, i sve ostalo je privid, sve što je između tih iskonskih pobjeda grijeha. I nije toliko nevolja u razbludnosti već u vjekovnom trajanju tuđeg zla, jačeg od prave vjere. Šta smo učinili, šta smo postigli, šta smo srušili, šta izgradili? (МC). Овде први референт асоцира са фразом tuđe zlo, а други скуп се осим изразом prava vjera, који асоцира са супротним знаком у односу на први, назначује још и глаголима у облику за 1. л. мн.: (smo) učinili, postigli, srušili, izgradili. Тј. то су дервиши из романа Дервиш и смрт, који ратују за праву веру.

Другу уочљивију групу чине случајеви када се конкретни референтни скуп базира на идеји о заједничкој националној, територијалној (или нпр. религијској) припадности, уп.: Иако на тој супротној страни света живе дивљаци, ја ипак нећу више да провлачим прсте кроз ту твоју прљаву косу... То је та страна где је ноћ кад је код нас дан и обратно: где је дан кад је код $\boldsymbol{\mu a c}$ ноћ (БН). Овде се у ствари фраза код нас не веже толико за референтни скуп људи који живе у Србији, колико за оне са северне полулопте, али се у оба случаја предикација схвата као она која има конкретну референцију за заменички облик у 1 . л. мн.

2.2. Понекад подразумевани скуп остаје са нејасном референцијом, али је упркос томе за аутора изражавана ситуација довољно разумљива, нпр.: „Sećam se jednog događaja koji se desio mnogo docnije (verovatno 1917) usred noći: bilo je možda tri sata posle ponoći. Odjednom smo se trgli iz sna (sigurno on i njegova devojka, jel da?) jer je neko strahovito udarao u vrata..." (МК). У овом одломку јунакиња чита својим друговима текст из књиге о једном сликару. И за њу и за њене слушаоце остаје нејасно о коме реферише израз trgli smo se iz sna, али аутор текста о сликару очигледно то не сматра препреком у перцепцији нарације. Међутим, радозналост подстиче јунакињу да се интересује за референта и да нагађа о њему из поменутих околности - ноћ је и неки скуп референата спава. Нејасну референцију неког скупа може сугерисати и подразумевана радња коју тај скуп врши, уп.: Spusti se, bre, malo na zemlju, iz tih svojih oblaka, i pogledaj u šta si se pretvorio! Nemoj pogrešno da me shvatiš, stari, ja stvarno ne obraćam pažnju na lovu, mislim, nije mi ona glavna preokupacija, ali ti nas zaista godinama praviš budalama! Dužan si na sve strane, pričaju ljudi ... (МК). Овде скуп сачињавају сви они који су јунаку позајмили новац; разумевање текста не тражи више од наведене информације.

Референцију која се односи на нејасан скуп имамо и у следећем примеру: Neprijatno mi je što po nekoliko puta susrećem ista lica; možda i za mene misle.: „Eno ludaka koga smo malo pre sreli kod „,Fontane”! Bože, kud god krenemo, naletimo na njega - šta li taj čovek večito radi po ulici, pa on je stalno napolju!" (МК). Овде је нејасноћа изазвана употребом неодређеноличног деагентивног глаголског облика мисле, који чува од визије агенса само најуопштенији 
обрис, који је довољан за сачињавање предикације. У следећим реченицама облик за 1 л. мн. реферише управо о том нејасном обрису агенса.

2.3. Шта више, референција експлицитног или подразумеваног заменичког облика за 1. л. мн. може да се под утицајем контекста промени и тада се осим улоге контекста испољава и улога наших ванјезичких знања о томе коју радњу ко врши. Такви облици за 1. л. мн. реферишу само на идеју о говорнику и о томе да он није сам. У следећем тексту: А професор поносито стоји над том гомилом, докми стењемо, он објашњава осталим ђацима планетни систем и кретање небеских тела кроз васиону. А можете мислити какву је панику тај професор произвео када нам је, полазећи са тога часа, рекао.... (БН) најпре заменица ми реферише само о тројици учесника у демонстрацији окретања планета, а затим реферише о свим ђацима из разреда. Али докле се овде промена у домету референције заменице може очекивати из фразе осталим ђацима, која допуњава референтни скуп, дотле у следећем тексту ту промену ништа не наговештава: Било јој је девет година и учила је трећи разред основне школе. Љубав сам јој исказао на један необично романтичан начин. Једном приликом када смо играли жмурке, ми се заједно сакријемо у једно буре, у коме је моја мајка зими киселила купус (БН). У последњој реченици најпре заменица ми ствара референцију која се односи на скуп субјеката који играју жмурке, а затим - на двоје деце која се крију од осталих. Разлика у референцији овде не рачуна толико на контекст, колико на наша ванјезичка знања о томе како се игра скривача.

2.4. У случајеве са конкретном референцијом иде и употреба облика за 1. л. мн. са референцијом која осим говорника укључује изричито и саговорника. Код основне употребе те врсте - у говорној ситуацији дијалога - понекад може бити и нејасно да ли скуп на који се односи облик ми укључује и друге референте осим говорника и саговорника. У монолошком тексту се, осим тога, појављује и једна посебна врста референтног скупа - хомогени скуп колектива читалаца (слушалаца).

2.4.1. Код класичне говорне ситуације - директног говора са саговорником - референт може да буде или да не буде назван ословљавањем у вокативу, а група може да укључује или да не укључује и друге референте, уп.: - ... svoju naklonost, ne toliko prema istom polu koliko prema svim bićima ,, osetljivijim od ovih agresivnih pejzana koji nas okružuju, draga moja”" (MK); - Ubili su ti brata. Hoćeš li da ga ovdje sahranimo? (MC).

2.4.2. Занимљивија је за нас друга говорна ситуација - она у којој аутор монолошког текста користи средства која опонашају језичка средства директног дијалога, а саговорник је колектив читалаца (у усменом тексту - слушалаца) - скуп субјеката с нејасном референцијом које у једну хомогену групу уједињује њихова функција адресата. У следећем примеру: Све су то ствари које су нашу дечју машту необично занимале, али морамо признати, и помогле да крај азбуке научимо и иифре и да тако свриимо и основну школу (БН) поново имамо промену у референцији: докле глаголи научимо и свршимо имају за агенса ученике из ауторовог разреда, дотле израз морамо признати реферише на колектив читалаца (заједно са говорником). Такву 
употребу коју називамо 'директан дијалог с колективом читалаца' имамо и у следећем примеру: ... а замислите на шта би јој личила тек цела математика, која је и нама изгледала као најкрволочнија животиња. И, ако бисмо јој тражили сличности у животиьском иуарству, она би најпре била слична одвратноме октоподу... (БН), где подразумевани агенс глаголског облика поново реферише о обема странама директног дијалога - о аутору/говорнику и о колективу читалаца/саговорника.

2.4.3. Слична размотреној употреби јесте и употреба коју условно називамо 'придруживање читаоца аутору'. И код ње облик за 1. л. реферише на аутора и на колектив читалаца. Међутим, овде се ради о средству којим аутор развија свој текст. Код ње у ствари аутор жели да своје намере у вези са изградњом текста прикаже као заједничке за њега и за колектив читалаца, уп.: ... док је ова глава аутобиографије намењена само оним сукњицама које служе као униформа средњем роду у граматици. Вратимо се дакле у ту малу сукьицу, у доба после првога зуба, после првих речи и после првих корака у живот (БН), уп.: Вратићу се у ту малу сукьииу. Или: Али да пођемо редом, од основне школе (БН) уместо Поћи ћу редом.

2.4.4. Исту референцију има облик за 1. л. у употреби коју називамо 'преношење искуства непознатог за саговорника' и која се традиционално користи у дидактичким текстовима, уп.: - Клин је тространа призма која се једном својом ивицом завлачи између два отпора које хоћемо да савладамо! - одговараш ти од речи до речи како си научио (БН). Овде аутор таквих израза не тежи нити опонашању директног дијалога нити прикривању својих намера у вези са изградњом текста. У ситуацији наставе ауторова комуникативна намера је да упути адресату помоћу облика за 1. л. множ. позив да мисли заједно с њим и као он. Уп. и у следећем примеру: Математичар: Ja бих из ове појаве извукао корен, односно не корен, него бих ја извукао једну корист. Ми имамо овде две познате количине: увређену апотекарску породииу, и писиа песме, плус саму песму. Ми бисмо из тих познатих могли добити непознату количину, тј. сазнати који су они остали што пишу песме о својим професорима (БН).

3. На први поглед сличну употребу онима које смо представили у претходној тачки 2.4.2. налазимо и у следећем примеру: И мада таква дечја питана изгледају бесмислена и смешна, ја ипак налазим да она нису без извесне логике, која је детету јасна, јер гледа на ствари и појаве непомућеним погледом, а која је старијима нејасна, јер што дубље улазе у живот, све више губе способност да ствари и појаве логички схватају. Узмимо баш као пример ових четири-пет питања која сам ја горе случајно набацао, па ћемо видети да су она не само за мене већ и за свако друго дете била сасвим логична (БН). У њему имамо горенаведену употребу 'директни дијалог са колективом читалаца'. Међутим, можемо без битне промене у семантици трансформисати последњу реченицу у погодбену: Ако узмемо бам као пример ових четири-пет питања која сам ја горе случајно набацао, видећемо да су она... при чему ће се омогућити следећа синонимна замена: Ако човек узме баш као пример..., видеће да су она... Том заменом улазимо у другу ос- 
новну врсту исказа са неназваним референтом - оних који немају конкретну референцију, него реферишу о једној генерализованој тачки гледишта, тј. у литератури познатих уопштеноличних исказа.

У свом истраживању ове врсте исказа ${ }^{1}$ одређујемо три прагматичка услова која дозвољавају њихову употребу: одговарајући одломак текста мора се употребити у говорном облику 'тумачење говорниковог животног искуства', учесник догађаја кроз чију се тачку гледишта тај догађај приказује мора бити дотакнут њиме (тј. догађај је за њега од посебног значаја) и говорник мора имати комуникативну намеру да својим исказом утиче активније на саговорника. У уопштеноличним (даље - УЛ) исказима се могу користити 4 врсте конструкција: 1) глаголи с актантом, најчешће у улози агенса, који заузима лексема са генерализованим значењем човек (у бугарском језику се она обавезно разликује од исте лексеме, али са генеричким значењем, тј. са значењем људске врсте, ${ }^{2}$ по свом облику без артикла; у српском језику разлика између ова два значења те лексеме нема формални израз); 2) глаголски и заменички облици за 2. лице једн., 1. л. множ. или 2. л. множ. Одређујемо и за бугарски и за српски језик судове са лексемом човек у генерализованом значењу као прототипске за уопштеноличне исказе, будући да њихова употреба најмање подлеже разним ограничењима у вези са контекстом.

Генерализовано значење дефинишемо као значење које не укључује референцију неког индивидуалног предмета (у ширем смислу) из ванјезичке стварности (без обзира да ли учесника у говорном чину или не), него субјекта говора, који укључује како саговорника тако и све остале могуће субјекте говора и који на тај начин остаје ван поделе по лицу (тј. по улози учесника / неучесника у говорном чину), уп. такво значење у исказу Човек никога не знае какво го чака (аз, ти, всички субекти на речта, т.е. всички говорещи никога не знаят/ Човек никад не зна шта га очекује (ја, ти, сви субјекти говора, тј. сви говорници никад не знају). За разлику од тога, генеричко значење именице човек реферише о апстрактној визији о роду, врсти субјеката која остаје у оквиру визије о трећем лицу - о објекту мишљења, о апстракцији која се налази изван личности говорника и саговорника (нпр. Човекът е разумно същество/ Човек је разумно створење).

Ситуације које се изражавају у УЛ исказима укључују понављане радње које може вршити свако. УЛ искази су језички израз уопштавајућих судова, код којих се по правилу четири наведене врсте УЛ средстава синонимно замењују, уп. горњи пример: Никад не знаш ита те очекује/ Никад не знамо шта нас очекује/ Никад не знате ита вас очекује. Па ипак, та се средства

\footnotetext{
${ }^{1} \mathrm{O}$ томе - Д. Савова, Обобщеноличните изказвания в българския език-прагматични манипулации на синтактично ниво (у штампи).

${ }^{2}$ УП. за генеричко значење, нпр., на бугарском: Човекъm е венец на природата; односно на српском: Jer sam se odjednom, /.../, osjetio umoran i klonuo, neugodno svjestan klopke, koja se ne tiče samo mene, i nije od juče. Čovjek je suviše izložen, i potrebna mu je zaštita (MC).

${ }^{3}$ Али не сви људи, зато што скуп свих људи јесте по свом екстензионалу максимални скуп субјеката-људи из ванјезичке стварности, створен помоћу универзалног квантификатора. За разлику од тога, скуп субјеката говора не реферише о ванјезичком субјекту-човеку, он може да на темељу функције говорника укључује и лисицу из бајке и дрвеће у песништву итд.
} 
разликују у суптилним семантичким нијансама, које задржавају далеку везу са одговарајућим граматичким обликом и који намећу извесна ограничења њиховој употреби. Таква нијанса код облика за 1. л. множ, који нас овде интересује, јесте далека идеја о колективу.

Да би употребио такав уопштавајући суд, који садржи генерализовани актант и изражава генерализовану ситуацију, говорник не приповеда о датом догађају, него, као што смо раније истакли, 1) тумачи своје животно искуство, 2) тиче га се дати конкретни догађај, који ће се приказати генерализовано, и 3) жели да активније утиче на саговорника. Језик му онда предлаже одређене синтаксичке конструкције којима се иначе изражавају и конкретне, негенерализоване ситуације. Таква синтаксичка конструкција је, нпр. зависна реченица за време: ... natjerali su i mene da se smiješim, ne naročito pametno, probudivši u meni zaspalu ili željenu dobrotu, kao kad gledamo djecu (MC), уп. синонимне замене са осталим врстама УЛ средстава: kao kad čovjek gleda djecu/ kao kad gledaš djecu/ kao kad gledate djecu. У том примеру употребљено је и друго синтаксичко средство, које дозвољава УЛ употребу - конструкција са значењем компарације (као); уп. и пример само са таквим значењем: Ili nešto slicno. Ima nekog posebnog uživanja u tom raspredanju, kao da smo iznad stvari (МС), у којем су могуће и остале УЛ варијанте: kao da je čovjek iznad stvaril kao da si iznad stvari/ kao da ste iznad stvari. Уопштавајући суд се може користити и у конструкцији са главним предикатом који изражава неку оцену, уп.: Ovaj kome nosiš pismo, na visokom je položaju. - To je još gore. Takvi misle da nam je čast što ih služimo (MC)/da je čovjeku čast što ih služi/ da ti je čast što ih služiš/ da vam je čast što ih služite. Могућност генерализованог тумачења пружа и суд у погодбеној реченици, какав је био случај вишенаведеног примера: Ако узмемо баш као пример ових четири-пет питаға која сам ја горе случајно набацао, видећемо да су она...

Специфичну употребу уопштавајућег суда имамо у говорном облику описа, када субјекат говора не приповеда, већ описује, нагомилава детаље из неког призора. Такву употребу називамо 'имагинарним призором', уп. следећи пример о њој: Ne tražim da mi kaže šta se s njim dešava, svako ima pravo da čuva svoju misao, ma kakva da je, a nije uvijek lako ni reći, često se vrtimo kao vjetrokaz, i ne možemo da odredimo svoj položaj, izbezumljeni nesigurnošću.

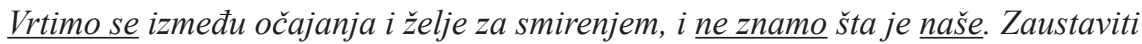
se u jednoj tački, okrenuti se prema jednoj strani, to je ono što treba a što je teško učiniti. Ma kakva odluka, osim one koja će uznemiravati našu savjest, bolja je od izgubljenosti kojom nas daruje neriješenost (MC). Овде придавању генерализоване перспективе, уз испуњење трију горенаведених услова за УЛ употребу (тумачење животног искуства ${ }^{4}$, дотакнутост догађајем и жеља да се активније утиче на саговорника), доприноси експлицирање семантике понављане

\footnotetext{
${ }^{4}$ УП. трансформацију код које говорник не намерава да тумачи своје животно искуство и да утиче активније на учесника сугеришући му своју тачку гледишта, него једноставно прича о себи: Ne tražim da mi kaže šta se s njim dešava, svako ima pravo da čuva svoju misao, ma kakva da je, a nije uvijek lako ni reći, često se vrtim kao vjetrokaz, i ne mogu da odredim svoj položaj, izbezumljen nesigurnošću.
} 
радње помоћу прилога често, а исто и модална семантика глагола не можемо. Модални глаголи у принципу омогућавају обликовање уопштавајућег суда, уп.: Smisao je gorak: čovjek treba da se odreče svega što bi mogao da zavoli, jer su gubitak i razočarenje neizbježni. Moramo se odreći ljubavi, da je ne izgubimo. Moramo uništiti svoju ljubav, da je ne unište drugi. Moramo se odreći svakog vezivanja, zbog mogućeg žaljenja. Misao je surovo beznadna. Ne možemo uništiti sve što volimo; uvijek će ostati mogućnost da nam to unište drugi (MC).

Има и других подврста конструкција које омогућују (уз присутност наведених трију основних чинилаца) употребу уопштавајућег суда у УЛ исказу. Међутим, овде ћемо истаћи да се понекад уопштавајући суд налази у контексту који намеће ограничења на синонимне замене УЛ средстава. Такав је, нпр., случај када се уопштавајући суд нађе у условима директног дијалога, нпр.: - Ne znam. A možda i nije istina. - Kasno je sad da se povlačiš. $\underline{\text { Ne }}$ možemo potrti što je rečeno. Poznajem li ga, tog što ti je ispričao? (MC). Будући да у директном дијалогу друго лице реферише о саговорнику, оно како у бугарском тако и у српском језику (за разлику, нпр. од руског) не може да се генерализује, а из неких других разлога у директном дијалогу није могућа ни УЛ употреба у 2. лицу множ. (тј. са ви у нереферентном, генерализованом значењу), постаје немогућа у њему УЛ замена са облицима за 2. л. једн. и множ., уп.: - Kasno je sad da se povlačiš. ${ }^{*}$ Ne možeš potrti što je rečeno/ *Ne možete potrti što je rečeno.

Пред синонимним заменама УЛ средстава стоји још низ других ограничења, од којих ћемо се ми овде осврнути и на још једно, о којем имамо много примера у ексцерпираном корпусу. Ради се о ограничењу пред употребом уопштавајућег суда када његов предикат има значење неке генеричке особине људског рода (особине специфичне за тај род), схваћеног као колектив, са идејом о плуралности (као што споменусмо, значење плуралности истиче управо облике за 1. л. мн.). Зато овде отпада као синонимна УЛ варијанта замена облицима за 2. л. једн., код којих остаје семантичка нијанса везе са саговорником као индивидуом (замена облицима за 2. л. множ. пак отпада из стилистичких разлога, на које се овде нећемо освртати). На тај начин уопштавајући суд у којем предикат има такву семантику генеричке особине може да укључује или конструкцију са генерализованом лексемом човек, или конструкцију са УЛ обликом у 1. л. множ., нпр.: Ми смо увек мање или више склони да осудимо оне који много говоре, нарочито о стварима које их се не тичу непосредно, чак и да са презиром говоримо о тим људима као о брбљивичима и досадним причалицама (ИА), уп.: Човек је увек мање или више склон да осуди оне који много говоре..., али немогућу УЛ замену са 2. л. једн.: *Ти си увек мағе или више склон да осудиш.., односно са 2. л. множ.: *Ви сте увек мање или више склони да осудите... .

Пред синонимном заменом са УЛ облицима у 1. л. множ. контекст може исто да ставља ограничења. Нпр., када је одговарајући одломак са тумачењем животног искуства смештен у оквир приповедања (које тече најчешће у плану прошлости), УЛ замена обликом за 1. л. множ. постаје немогућа, зато што тај облик изражава идеју о колективу који укључује истовремено и говорника 
и саговорника, а приповедање о неким догађајима претпоставља да саговорник о њима не зна. Зато ће се у таквим случајевима, ако је облик за 1. л. множ. могућ, тај облик перципирати као референтан (а не УЛ) скуп који изузима саговорника, рецимо: Sitna, slaba na izgled, još mlada, nije izazivala pažnju odmah, ali su njen sabran pogled i mirni pokreti i sigurnost ponašanja natjerivali čovjeka da ne prođe mimo nju ravnodušno (MC), уп. немогуће: * ..., ali su njen sabran pogled i mirni pokreti i sigurnost ponašanja natjerivali nas da ne prođemo mimo nju ravnodušno. Постоји и низ других ограничења пред УЛ употребом разматраних облика, али се овде нећемо на њих детаљно освртати.

4. На крају ћемо извести следеће закључке.

4.1. У монолошком тексту, као што смо видели, контекст остаје једини фактор који одређује идентификацију референтног скупа на који се односи одговарајући заменички облик ми и/или глаголски облик за 1. лице множине. У дијалошком тексту се тај фактор укључује када основни чинилац - говорна ситуација, престаје да врши своју идентификацијску функцију (уп. горенаведени пример: - Kasno je sad da se povlačis. Ne možemo potrti što je rečeno, где из семантике реченице најпре постаје јасно да се не реферише о говорнику са саговорником или без њега и да је, према томе, то генерализовано значење). Идентификација на темељу контекста у монолошком тексту разликује се од идентификације на бази говорне ситуације у дијалогу, пошто она пролази кроз различите логичке механизме. Осим тога, она дозвољава и извесну нејасноћу, која се у усменом дијалогу обично уклања прецизирајућим питањима. Дозвољена је и промена референције коју не сигнализује ниједно формално средство.

4.2. У монолошком тексту облик за 1. л. множ. може да ствара и специфичну референцију која се односи на скуп који укључује осим говорника још и једну хомогену групу имагинарних адресата, која се не мења у различитим контекстима јер се визија имагинарних адресата-читалаца исто не мења. Чак и ако та група укључује аудиторијум слушалаца, за референцију одговарајућих језичких израза није од значаја које су конкретно индивидуе укључене у њу. У различитим говорним чиновима мења се само аутор, тј. говорник. Тај тип референције користи се у неке конкретније комуникативне сврхе аутора.

4.3. Референција УЛ облика за 1. л. множ. јесте резултат једне језичке манипулације, која говорнику дозвољава да активније утиче на саговорника. Вршење манипулације не само што не укључује као потребну идентификацију референтног скупа - њој треба управо супротно: да сакрије праву референцију учесника у говорној ситуацији помоћу генерализације субјекта говора. 


\section{ЛИТЕРАТУРА}

Барић и др. 2005: E. Barić, M. Lončarić, D. Malić, S. Pavešić, M. Peti, V. Zečević, M. Znika, Hrvatska gramatika, Zagreb: Školska knjiga.

Бенвенист 1974: Е. Бенвенист, Общая лингвистика, https://classes.ru/ grammar/167.Benvenist-common-linguistics/source/worddocuments/xx.htm, 10.10.2018.

Ницолова 1986: Р. Ницолова, Българските местоимения, София: Наука и изкуство.

\section{ИЗВОРИ ЕКСЦЕРПИРАНЕ ГРАЂЕ}

БН - Бранислав Нушић, Аутобиографија, http://www.rastko.rs/rastko/delo/11228, 10.10.2018.

ИА - Иво Андрић, Проклета авлија, https://tszoricaivanovic.files.wordpress. com/2013/09/ivo-andric-prokleta-avlija.pdf, 10.10.2018.

MK-Momo Kapor, Foliranti, http://www.skripta.info/wp-content/uploads/2016/12/ Momo-Kapor-Foliranti.pdf, 10.10.2018.

MC - Meša Selimović, Derviš i smrt, http://rs.vetarsabalkana.com/d/567117/d/ mesa-selimovic-dervis-i-smrt.pdf, 10.10.2018.

Димка В. Савова

ГЛАГОЛЬНЫЕ И МЕСТОИМЕННЫЕ ФОРМЫ 1. Л. МН. Ч. С НЕНАЗВАННЫМ РЕФЕРЕНТОМ И ЗАВИСИМОСТЬ ИХ РЕФЕРЕНЦИИ ОТ КОНТЕКСТА

Резюме

В работе рассматривается вопрос о референции местоименных и глагольных форм 1. л. множ. числа. Выделяются основные разновидности их употребления в зависимости от их контекста. Намечаются основные различия между употреблениями в диалогической и монологической речи, как и в конкретнореферентном, соответственно, в генерализированном значении. Ключевые слова: референция, контекст, генерализированное значение. 